medRxiv preprint doi: https://doi.org/10.1101/2021.04.29.21256334; this version posted May 1, 2021. The copyright holder for this preprint (which was not certified by peer review) is the author/funder, who has granted medRxiv a license to display the preprint in perpetuity. It is made available under a CC-BY-NC-ND 4.0 International license .

\title{
Association of depression screening with diagnostic and treatment-related outcomes among
} youth

Kira E. Riehm ${ }^{\mathrm{a}}$, MSc; Emily Brignone ${ }^{\mathrm{b}}$, PhD; Elizabeth A. Stuart ${ }^{\mathrm{a}}, \mathrm{PhD}$; Joseph J. Gallo ${ }^{\mathrm{a}, \mathrm{c}}$, MD MPH; Ramin Mojtabai ${ }^{\mathrm{a}}$, MD

Affiliations: ${ }^{\text {a}}$ Department of Mental Health, Bloomberg School of Public Health, Johns Hopkins University, Baltimore, Maryland, USA; ${ }^{b}$ Data Science Research and Development, Highmark Health, Pittsburgh, Pennsylvania, USA; ${ }^{\circ}$ Department of Psychiatry \& Behavioral Sciences, Johns Hopkins School of Medicine, Baltimore, Maryland, USA

Address correspondence to: Kira E. Riehm; 624 N Broadway, Baltimore, MD, USA 21205; 443-600-6265; kriehm1@jhu.edu

Short Title: Outcomes of depression screening in youth

Conflict of Interest Disclosures (includes financial disclosures): The authors have no conflicts of interest relevant to this article to disclose.

Funding/Support: Ms. Riehm was supported by a Ruth L. Kirschstein National Research Service Award from the National Institute of Mental Health (1F31MH124330-01) and by a Doctoral Foreign Study Award from the Canadian Institutes of Health Research.

Role of Funder/Sponsor (if any): The National Institute of Mental Health and the Canadian Institutes of Health Research had no role in the design and conduct of this study.

\section{Clinical Trial Registration (if any): N/A}

Abbreviations: Blue Cross Blue Shield (BCBS); Current Procedural Terminology (CPT); Healthcare Common Procedure Coding System (HCPCS); International Classification of Diseases (ICD); Randomized controlled trial (RCT); Relative risk (RR); United States (US); United States Preventive Services Task Force (USPSTF)

\section{Table of Contents Summary}

Insurance claims data were used to explore associations between depression screening during routine well-visits and depression diagnoses, psychiatric prescriptions, and psychotherapy among adolescents.

\section{What's Known on This Subject}

Depression screening is increasingly viewed as a key strategy for addressing depression among adolescents. To inform clinical guidelines, the United States Preventive Services Task Force has called for research to examine the diagnostic and treatment-related outcomes of depression screening.

\section{What This Study Adds}


medRxiv preprint doi: https://doi.org/10.1101/2021.04.29.21256334; this version posted May 1, 2021. The copyright holder for this preprint (which was not certified by peer review) is the author/funder, who has granted medRxiv a license to display the preprint in perpetuity.

It is made available under a CC-BY-NC-ND 4.0 International license .

In a sample of 57,732 adolescents, adolescents who were screened for depression during a wellvisit were more likely to receive a depression or mood-related diagnosis over 6-month follow-up, but were not more likely to be treated with medication or psychotherapy. 
medRxiv preprint doi: https://doi.org/10.1101/2021.04.29.21256334; this version posted May 1, 2021. The copyright holder for this preprint (which was not certified by peer review) is the author/funder, who has granted medRxiv a license to display the preprint in perpetuity.

It is made available under a CC-BY-NC-ND 4.0 International license .

\section{Contributors' Statement Page}

Ms. Riehm conceptualized and designed the study, cleaned and analyzed the data, drafted the initial manuscript, and reviewed and revised the manuscript.

Dr. Brignone assembled the dataset and reviewed the manuscript.

Dr. Stuart, Dr. Gallo, and Dr. Mojtabai assisted in designing the analytic approach, interpreting results, and reviewing the manuscript.

All authors approved the final manuscript as submitted and agree to be accountable for all aspects of the work. 
medRxiv preprint doi: https://doi.org/10.1101/2021.04.29.21256334; this version posted May 1, 2021. The copyright holder for this preprint (which was not certified by peer review) is the author/funder, who has granted medRxiv a license to display the preprint in perpetuity.

It is made available under a CC-BY-NC-ND 4.0 International license .

\begin{abstract}
Background and Objectives

The goals of depression screening, which is universally recommended in primary care settings in the U.S., are to identify adolescents with depression and connect them to treatment. However, little is known about how depression screening affects the likelihood of being diagnosed with a mental disorder or accessing mental health care over time.
\end{abstract}

\title{
Methods
}

This longitudinal cohort study used insurance claims data from 57,732 adolescents who had at least one routine well-visit between 2014 and 2017. Using propensity score matching, we compared adolescents who were screened for depression to similar adolescents who were not screened for depression during the well-visit. Diagnostic and treatment-related outcomes were examined over 6-month follow-up and included depression diagnoses, mood-related diagnoses, antidepressant prescriptions, any mental health-related prescriptions, and psychotherapy. We also examined heterogeneity of associations by sex.

\section{Results}

Compared to adolescents who were not screened for depression, adolescents screened for depression were $30 \%$ more likely to be diagnosed with depression ( $\mathrm{RR}=1.30,95 \% \mathrm{CI}=1.11$ $1.52)$ and $17 \%$ more likely to receive a mood-related diagnosis $(\mathrm{RR}=1.17,95 \% \mathrm{CI}=1.08-1.27)$, but were not more likely to be treated with an antidepressant prescription ( $\mathrm{RR}=1.11,95 \%$ $\mathrm{CI}=0.82-1.51)$, any mental health prescription $(\mathrm{RR}=1.15,95 \% \mathrm{CI}=0.87-1.53)$, or psychotherapy $(\mathrm{RR}=1.13,95 \% \mathrm{CI}=0.98-1.31)$. In general, associations were stronger among females.

\section{Conclusions}

Adolescents who were screened for depression during a well-visit were more likely to receive a diagnosis of depression or a mood-related disorder in the six months following screening. Future research should explore methods for increasing access to treatment and treatment uptake following screening. 
medRxiv preprint doi: https://doi.org/10.1101/2021.04.29.21256334; this version posted May 1, 2021. The copyright holder for this preprint (which was not certified by peer review) is the author/funder, who has granted medRxiv a license to display the preprint in perpetuity.

It is made available under a CC-BY-NC-ND 4.0 International license .

\section{INTRODUCTION}

Depression is a leading cause of morbidity and functional impairment among adolescents. ${ }^{1}$ Left untreated, adolescent depression can have adverse consequences for wellbeing in adulthood, including chronicity of depressive symptoms, onset of other mental health disorders, incidence of somatic conditions, and premature mortality. ${ }^{2-5}$ Accumulating evidence suggests that the prevalence of major depressive episodes and depressive symptoms has increased among adolescents over the past decade in the U.S. ${ }^{6,7}$ Together, the negative outcomes associated with depression and rising rates over time demand action to reduce the burden of this mental health problem among adolescents.

The accurate identification of depressive symptoms is a prerequisite to treatment. However, prior studies have found that primary care providers may fail to identify up to twothirds of adolescents with depression. ${ }^{8,9}$ Screening has been proposed as one method of increasing the detection of depression, which could in turn connect a greater number of patients to mental health care and lead to improved health outcomes. ${ }^{10}$ Universal depression screening is currently recommended in primary care settings for adolescents by the U.S. Preventive Services Task Force (USPSTF), ${ }^{11}$ but this recommendation is controversial, with some researchers pointing to a lack of evidence for improved outcomes following screening. ${ }^{10,12}$

At present, there are no randomized controlled trials (RCTs) that compare depression screening to usual care in primary care settings among adolescents. ${ }^{12}$ Although RCTs are considered the gold standard of evidence for assessing the effects of interventions on health, ${ }^{13}$ an RCT of depression screening in primary care, comparing screened to unscreened adolescents, may not be considered ethically sound because of the universal USPSTF recommendation. ${ }^{11}$ Instead, evidence for depression screening is often inferred from studies of collaborative care or 
medRxiv preprint doi: https://doi.org/10.1101/2021.04.29.21256334; this version posted May 1, 2021. The copyright holder for this preprint (which was not certified by peer review) is the author/funder, who has granted medRxiv a license to display the preprint in perpetuity. It is made available under a CC-BY-NC-ND 4.0 International license .

education programs for providers, ${ }^{14-17}$ which are unlikely to generalize to primary care settings where such care or education are unavailable. To better inform clinical guidelines, decision makers have called for research to examine the longitudinal outcomes of depression screening. ${ }^{11}$

In the absence of evidence from RCTs, the application of causal inference methods to observational data provides an important opportunity to estimate the effect of depression screening on outcomes among adolescents. Because physicians may be more likely to screen adolescents they suspect are depressed, ${ }^{18}$ to compare the outcomes of screened and non-screened adolescents, we used propensity scores to account for characteristics associated with being screened in the first place. The objectives of this study were (1) to examine the prospective association of being screened for depression during routine well-visits with diagnostic and treatment-related outcomes among adolescents and (2) to determine if associations varied by sex. We hypothesized that adolescents screened for depression would be more likely to receive a diagnosis of depression and be treated for it in the six months following screening, compared to adolescents not screened for depression.

\section{METHODS}

\section{Participants}

Healthcare claims and pharmacy claims data were obtained from Highmark Health, a non-profit healthcare organization. ${ }^{19}$ The data include Blue Cross Blue Shield (BCBS) members with commercial (large group, small group, and participants who acquired individual or small group insurance through Affordable Care Act Marketplace) or Medicare Advantage insurance. The largest membership is in Pennsylvania, West Virginia, and Delaware, where Highmark Health is the BCBS insurer; however, members live across the U.S. due to large national accounts. 
medRxiv preprint doi: https://doi.org/10.1101/2021.04.29.21256334; this version posted May 1, 2021. The copyright holder for this preprint (which was not certified by peer review) is the author/funder, who has granted medRxiv a license to display the preprint in perpetuity. It is made available under a CC-BY-NC-ND 4.0 International license .

This study used a retrospective cohort design. Participants who met the following criteria were included: (1) had a well-visit (V20.2, V70.0, Z00.121, Z00.129, Z00.00, Z00.01, 99384, 99394, 99385, or 99395) in primary care or general pediatric settings after January 1st, 2014 and before December 31st, 2017 (hereafter referred to as the index well-visit); (2) were continuously enrolled for at least six months before and two years after the index well-visit; and (3) were aged 12-18 (the age group that the USPSTF guidelines apply to) at the time of the index well-visit. For participants with more than one well-visit during the study period, we selected the first well-visit to maximize available follow-up time. In line with other studies, ${ }^{20}$ we excluded adolescents who had a diagnosis of depression, an anti-depressant prescription, or psychotherapy treatment in the six months prior to the index well-visit. Because our interest was in short-term outcomes following depression screening, we selected a follow-up period that extended for six months after the index well-visit.

Of the 281,463 adolescents with a well-visit recorded between 2014 and 2017, we included 57,732 in our propensity score-matched sample; a flow diagram for participant selection is displayed in Supplementary Figure 1.

\section{Measures}

Depression Screening. Depression screening was defined according to a combination of ICD-9, ICD-10, Current Procedural Terminology (CPT), and Healthcare Common Procedure Coding System (HCPCS) codes. Similar to a prior study, ${ }^{20}$ adolescents were coded as having been screened for depression during the index well-visit if at least one of the following codes was recorded: G0444, G8510, 96127, 99420, V79.0, and/or Z13.89. A description of each code, and the proportion of well-visits with each code recorded, is presented in Supplementary Table 1. 
medRxiv preprint doi: https://doi.org/10.1101/2021.04.29.21256334; this version posted May 1, 2021. The copyright holder for this preprint (which was not certified by peer review) is the author/funder, who has granted medRxiv a license to display the preprint in perpetuity. It is made available under a CC-BY-NC-ND 4.0 International license .

Depression Diagnosis. Because general medical providers tend to use non-specific mood diagnostic categories to identify depressive disorders, ${ }^{21}$ two diagnostic outcomes were used in this study: a narrower diagnosis of depression, and a broader definition of any mood-related diagnosis. We defined these according to peer-reviewed, validated definitions where available; if not, we used definitions from prior studies. Depression diagnoses were identified by ICD-9 codes 296.20-296.25, 296.30-296.35, 300.4, 309.0, 309.1, 309.28 and 311 and ICD-10 codes F31.3-F31.6, F32.0- 32.9, F33.0-33.3, F33.8, F33.9, F34.1, F34.8, F34.9, F38.0, F38.1, F38.8, F39, F41.2, and F99. ${ }^{22}$ Mood-related diagnoses were identified with ICD-9 codes 296, 300, 307 309, 311, and 313 and ICD-10 codes F30-F48, F93, and F99. ${ }^{17}$

Depression Treatment. The treatment-related outcomes were ascertained from CPT codes and included medication treatment as well as psychotherapy. We separately examined antidepressant medications and any mental health medication (antidepressants, mood-stabilizers, anti-anxiety medications, anti-psychotic medications, and medications to treat attention-deficit hyperactivity disorder); a list of medications included is provided in Supplementary Table 2. A list of the CPT codes included to identify psychotherapy is in Supplementary Table 3.

Covariates. We selected characteristics likely to be associated with both selection for depression screening and depression outcomes based on existing literature. ${ }^{18,20}$ Age (years) and sex (male and female) were obtained from claims data. Race/ethnicity (Asian, Black, Hispanic/Latino, other, and White) was estimated using the wru R package, which applies Bayesian methods to generate predicted probabilities for each race/ethnicity category for a given person based on geolocation and other individual characteristics. ${ }^{23}$ Rurality was defined using Rural-Urban Commuting Area codes from 2010 (the most recent available), which are provided at the ZIP level; these codes were aggregated into three categories (urban, large rural city/town, 
medRxiv preprint doi: https://doi.org/10.1101/2021.04.29.21256334; this version posted May 1, 2021. The copyright holder for this preprint (which was not certified by peer review) is the author/funder, who has granted medRxiv a license to display the preprint in perpetuity. It is made available under a CC-BY-NC-ND 4.0 International license .

and small/isolated rural town). Prior emergency health services use was defined as the count of encounters with emergency or urgent care services in the six months prior to the index well-visit. Prior routine health services use was defined as the count of encounters with outpatient, primary care, and preventive services in the six months prior to the index well-visit. Physical health comorbidities were defined by the count of encounters in the six months prior to the index wellvisit where an ICD code for a given category of the Charlson Comorbidity Index was recorded. Data for ZIP-level median household income were obtained from the American Community Survey from 2006-2010. ${ }^{24}$ The medical specialties of the health care providers performing the well-visits were aggregated into three categories (child- or adolescent-specific, family-specific, and other primary care).

\section{Statistical Analysis}

Propensity Score Estimation. Our objective was to estimate the effect of being screened for depression, compared to not being screened for depression, on diagnostic and treatmentrelated outcomes. To this end, we used propensity score matching to account for confounding of the association between screening and outcomes by the covariates listed above. Propensity scores are a causal inference technique that can be applied to observational data to emulate some qualities of RCTs and estimate treatment effects when full-scale RCTs are not feasible. ${ }^{25}$ We used nearest neighbor matching without replacement, selecting three unscreened adolescents for each screened adolescent. Matches were selected based on a propensity score estimated using a logistic regression model with depression screening as the dependent variable and the covariates as independent variables. To account for hypothesized moderation by sex, we included interaction terms between sex and each covariate in the propensity score model and used exact matching for sex. ${ }^{26}$ Figure 1 displays standardized mean differences (SMDs) for all covariates 
medRxiv preprint doi: https://doi.org/10.1101/2021.04.29.21256334; this version posted May 1, 2021. The copyright holder for this preprint (which was not certified by peer review) is the author/funder, who has granted medRxiv a license to display the preprint in perpetuity. It is made available under a CC-BY-NC-ND 4.0 International license .

before and after matching. After matching, SMDs for all covariates were less than 0.1, indicating that the matching procedure improved balance between screened and unscreened adolescents on observed covariates. The matched sample $(n=57,732)$ was composed of 14,433 screened and 43,299 unscreened adolescents.

Descriptive Characteristics. We examined descriptive statistics in both the complete sample and the propensity score-matched sample. We also examined changes in the proportion of adolescents screened over time.

\section{Association of Depression Screening with Diagnostic and Treatment-Related}

Outcomes. To estimate the effect of depression screening on each outcome, we estimated a series of log-binomial regression models using the matched sample with depression screening as the independent variable. To determine if the effect of depression screening on each outcome varied by sex, we estimated the same series of models including an interaction term between depression screening and sex. Coefficients for the depression screening variable were exponentiated for interpretation as risk ratios (RRs) representing the average effect of screening among those who were screened (i.e., the average treatment effect among the treated). Standard errors in all models were estimated using cluster-robust variance estimates to account for matched clusters.

Sensitivity Analysis. Our study period coincided with the implementation of ICD-10 in the U.S. on October 1, 2015. To test the sensitivity of our findings to the change in coding system, we re-estimated our models with an interaction term between depression screening and an indicator variable for whether an index well-visit occurred before or after October 1, 2015. We also tested the sensitivity of significant parameter estimates to unmeasured confounding by calculating e-values, which convey the minimum strength of association that an unmeasured 
medRxiv preprint doi: https://doi.org/10.1101/2021.04.29.21256334; this version posted May 1, 2021. The copyright holder for this preprint (which was not certified by peer review) is the author/funder, who has granted medRxiv a license to display the preprint in perpetuity.

It is made available under a CC-BY-NC-ND 4.0 International license .

confounder would need to have with both the depression screening and each outcome to fully

explain away associations. ${ }^{27}$

Statistical significance was assessed at $\mathrm{p}<.05$. All analyses were conducted using $\mathrm{R}(\mathrm{R}$ studio version 1.2.5042; $\mathrm{R}$ version 4.0.0). This study was reviewed by the Johns Hopkins Institutional Review Board and was determined to be human subjects research that meets criteria for exemption under category four (i.e., secondary analysis of existing, de-identified data).

\section{RESULTS}

\section{Descriptive Characteristics}

Descriptive characteristics for the complete and matched samples are displayed in Table 1. The sample of 248,354 adolescents had a mean age of 14.26 years (standard deviation $[\mathrm{SD}]=2.06)$ and $121,432(48.9 \%)$ were female. In the 6-month period following the index wellvisit, 4,730 (1.9\%) adolescents received a depression diagnosis, 13,591 (5.5\%) received a moodrelated diagnosis, $1,330(0.5 \%)$ were treated with antidepressants, 5,182 $(2.1 \%)$ were treated with a prescription for any mental health condition, and 6,394 (2.6\%) were treated with psychotherapy.

The percentage of adolescents screened for depression during the index well-visit increased across the study period (Figure 2). In 2014, approximately $2.0 \%$ of adolescents were screened for depression during the index well-visit; in contrast, of adolescents who had their index well-visit in $2017,13.6 \%$ were screened.

\section{Association of Depression Screening with Diagnostic and Treatment-Related Outcomes}

Results of the propensity score matched analyses are displayed in Table 2. Compared to adolescents not screened for depression, those who were screened during the index well-visit were $30 \%$ more likely to be diagnosed with depression $(\mathrm{RR}=1.30,95 \% \mathrm{CI}=1.11-1.52)$ and $17 \%$ 
medRxiv preprint doi: https://doi.org/10.1101/2021.04.29.21256334; this version posted May 1, 2021. The copyright holder for this preprint (which was not certified by peer review) is the author/funder, who has granted medRxiv a license to display the preprint in perpetuity. It is made available under a CC-BY-NC-ND 4.0 International license .

more likely to receive a mood-related diagnosis $(\mathrm{RR}=1.17,95 \% \mathrm{CI}=1.08-1.27)$ across six-month follow-up. Being screened for depression was not associated with antidepressant prescriptions $(\mathrm{RR}=1.11,95 \% \mathrm{CI}=0.82-1.51)$, any mental health prescriptions $(\mathrm{RR}=1.15,95 \% \mathrm{CI}=0.87-1.53)$, or psychotherapy $(\mathrm{RR}=1.13,95 \% \mathrm{CI}=0.98-1.31)$.

In stratified analyses (Table 2), females who were screened for depression were significantly more likely to be diagnosed with depression $(\mathrm{R}=1.42,95 \% \mathrm{CI}=1.17-1.71)$, to receive a mood-related diagnosis $(\mathrm{RR}=1.26,95 \% \mathrm{CI}=1.12-1.40)$, and to be treated with psychotherapy $(\mathrm{RR}=1.22,95 \% \mathrm{CI}=1.05-1.43)$, compared to females not screened for depression. These same associations were not significant among males (depression diagnosis: $\mathrm{RR}=1.12,95 \%$ $\mathrm{CI}=0.87-1.44$; mood-related diagnosis: $\mathrm{RR}=1.06,95 \% \mathrm{CI}=0.93-1.22$; psychotherapy: $\mathrm{RR}=1.02$, 95\% CI=0.84-1.23). However, interactions terms between depression screening and sex were not statistically significant for any outcome.

\section{Sensitivity Analysis}

Interaction terms between depression screening and an indicator variable for whether an index well-visit occurred before or after October 1, 2015 were not significant in models for any outcome, indicating that our results were unlikely to have been influenced by the implementation of ICD-10. E-values for significant parameter estimates are presented in Supplementary Table 4. The observed risk ratios of 1.30 and 1.17 for depression diagnoses and mood-related diagnoses could be explained away by an unmeasured confounder that was associated with both depression screening and these outcomes by a risk ratios of 1.92 and 1.62 , respectively, above and beyond the measured confounders, but weaker confounding could not do so. Given other aspects of our study design, namely the exclusion of those with recent depression diagnoses and/or depression 
medRxiv preprint doi: https://doi.org/10.1101/2021.04.29.21256334; this version posted May 1, 2021. The copyright holder for this preprint (which was not certified by peer review) is the author/funder, who has granted medRxiv a license to display the preprint in perpetuity. It is made available under a CC-BY-NC-ND 4.0 International license .

treatment, we interpret these e-values as indicating that unmeasured confounding is possible but unlikely.

\section{DISCUSSION}

In this study, we found that adolescents who were screened for depression during a wellvisit were more likely to subsequently be diagnosed with depression or a mood-related condition over six-month follow-up. However, they were not more likely to fill an antidepressant or other mental health prescription, nor receive psychotherapy. Associations between depression screening and outcomes were generally stronger among females compared to males.

Our study builds on prior findings ${ }^{17,28-31}$ by using rigorous causal inference methods to examine longitudinal outcomes of depression screening in a large, population-based sample of adolescents. Our results suggest that depression screening may increase identification of depression and other behavioral health conditions but may not reduce unmet need for care. The USPSTF recommendation for depression screening states that "adequate systems should be in place to ensure accurate diagnosis, effective treatment, and appropriate follow-up" ${ }^{11}$ following screening. However, others have noted that primary care settings rarely have these systems in place due to scarce treatment resources and inadequate funding to support training of providers. ${ }^{32}$ The scope of our study precludes examining factors that may have played a role in lack of treatment uptake, but broadly, our findings suggest that structural barriers may limit successful engagement in treatment following screening. We also observed that the proportion of adolescents screened for depression during the index well-visit increased over time. Altogether, this suggests that over time, increasing number of adolescents are identified as depressed but go untreated, which highlights the urgency of addressing barriers to care. 
medRxiv preprint doi: https://doi.org/10.1101/2021.04.29.21256334; this version posted May 1, 2021. The copyright holder for this preprint (which was not certified by peer review) is the author/funder, who has granted medRxiv a license to display the preprint in perpetuity. It is made available under a CC-BY-NC-ND 4.0 International license .

We observed some evidence of heterogeneity by sex; associations between depression screening and outcomes tended to be stronger among female adolescents compared to males. A well-replicated finding is that males tend to report greater mental health stigma, which serves as a substantial deterrent to help-seeking. ${ }^{33}$ In the context of depression screening, males may be more reluctant than females to engage in follow-up care. Another explanation is that males may express depression differently from females, with greater symptoms of anger, irritability, and emotional numbness. ${ }^{34}$ These symptoms are not commonly assessed with generic screening tools and may not be recognized as depression.

A number of strategies have been introduced to increase mental health services utilization among adolescents. Prior studies have noted the central role that parents play in the depression screening process; in particular, many primary care providers perceive parental resistance to diagnosis and negative attitudes toward treatment to be key barriers to adolescent entry to treatment. ${ }^{35}$ Instead of viewing parental attitudes as a barrier to care, active approaches that provide psychoeducation to parents and involve them in routine treatment decisions are likely to be more effective at ensuring treatment needs are met. ${ }^{36}$ Preliminary studies of "warm handoffs," where an adolescent is introduced to a behavioral health provider at the time of referral, have been found to increase the likelihood of attendance at follow-up appointments; ${ }^{37,38}$ however, these models may only be feasible in integrated settings where behavioral health providers are on-site. Other strategies have focused on integration of psychosocial screening tools into electronic health records and the use of computer-based decision support systems, which can improve workflow and streamline referral processes. ${ }^{30,39-41}$ Broader policy-based efforts are also critical for increasing the supply of mental health providers, as well as employing consultation models whereby psychiatrists can guide the management of adolescent mental 
medRxiv preprint doi: https://doi.org/10.1101/2021.04.29.21256334; this version posted May 1, 2021. The copyright holder for this preprint (which was not certified by peer review) is the author/funder, who has granted medRxiv a license to display the preprint in perpetuity.

It is made available under a CC-BY-NC-ND 4.0 International license .

health problems by primary care providers. ${ }^{42}$ Finally, the COVID-19 pandemic has resulted in rapid roll-out of telehealth services, and there is hope that these services can help overcome geographic and financial barriers to care. ${ }^{43}$

Some limitations of this study should be noted. The sample used in this study is based primarily in the Eastern U.S. and may not generalize to the country as a whole. We used health insurance claims data, which are limited in the amount of information they can provide about a given medical encounter. For example, we were unable to access the results of depression screening procedures. Although we used validated exposure and outcome definitions where possible, the accuracy of claims data in reflecting certain procedures and health outcomes remains an area of active research. ${ }^{44}$ Adolescents in our sample may have accessed mental health treatment not covered by insurance, which would not have been captured by claims data. Finally, propensity scores cannot guarantee balance on unobserved confounders, though our sensitivity analyses suggested that residual confounding is unlikely. On the other hand, strengths of this study include the use of a large, longitudinal sample to examine rare outcomes and the application of rigorous causal inference methods to estimate effects.

In summary, this study found that adolescents who were screened for depression during a well-visit were more likely to receive a diagnosis of depression or a mood-related disorder in the six months following screening; however, they were not more likely to be treated with prescription medication or psychotherapy. Associations between screening and outcomes were generally stronger among females compared to males. Future studies should examine long-term health outcomes of depression screening, as well as the implementation of strategies to increase treatment uptake among adolescents. 
medRxiv preprint doi: https://doi.org/10.1101/2021.04.29.21256334; this version posted May 1, 2021. The copyright holder for this preprint (which was not certified by peer review) is the author/funder, who has granted medRxiv a license to display the preprint in perpetuity. It is made available under a CC-BY-NC-ND 4.0 International license .

\section{References}

1. Thapar A, Collishaw S, Pine DS, et al. Depression in adolescence. Lancet. 2012;379(9820):1056-1067.

2. Colman I, Wadsworth MEJ, Croudace TJ, et al. Forty-Year Psychiatric Outcomes Following Assessment for Internalizing Disorder in Adolescence. Am J Psychiatry. 2007;164(1):126-133.

3. Weissman MM, Wolk S, Goldstein RB, et al. Depressed Adolescents Grown Up. JAMA. 1999;281(18):1707-1713.

4. Clayborne ZM, Varin M, Colman I. Systematic Review and Meta-Analysis: Adolescent Depression and Long-Term Psychosocial Outcomes. J Am Acad Child Adolesc Psychiatry. 2019;58(1):72-79.

5. Leone M, Kuja-Halkola R, Leval A, et al. Association of Youth Depression With Subsequent Somatic Diseases and Premature Death. JAMA Psychiatry. 2020.

6. Mojtabai R, Olfson M, Han B. National Trends in the Prevalence and Treatment of Depression in Adolescents and Young Adults. Pediatrics. 2016;138(6):e20161878.

7. Keyes KM, Gary D, O’Malley PM, et al. Recent increases in depressive symptoms among US adolescents: trends from 1991 to 2018. Soc Psychiatry Psychiatr Epidemiol. 2019;54(8):987-996.

8. Leaf PJ, Alegria M, Cohen P, et al. Mental health service use in the community and schools: Results from the four-community MECA study. J Am Acad Child Adolesc Psychiatry. 1996;35(7):889-897.

9. Burns BJ, Costello EJ, Angold A, et al. Children's mental health service use across service sectors. Health Aff. 1995;14(3):147-159.

10. Mojtabai R. Universal depression screening to improve depression outcomes in primary care: sounds good, but where is the evidence? Psychiatr Serv. 2017;68(7):724-726.

11. Siu AL. Screening for Depression in Children and Adolescents: US Preventive Services Task Force Recommendation Statement. Pediatrics. 2016;137(3):e20154467.

12. Roseman M, Saadat N, Riehm KE, et al. Depression Screening and Health Outcomes in Children and Adolescents: A Systematic Review. Can J Psychiatry. 2017;62(12):813817.

13. Stuart EA. Matching methods for causal inference: A review and a look forward. Stat Sci. 2010;25(1):1-21.

14. Bakken S, Jia H, Chen ES, et al. The effect of a mobile health decision support system on diagnosis and management of obesity, tobacco use, and depression in adults and children. J Nurse Pract. 2014;10(10):774-780.

15. Fallucco EM, James L, Smotherman C, et al. Impact of Experiential Training With Standardized Patients on Screening and Diagnosis of Adolescent Depression in Primary Care. J Adolesc Health. 2019;65(1):57-62.

16. Kramer T, Iliffe S, Bye A, et al. Testing the feasibility of therapeutic identification of depression in young people in British general practice. J Adolesc Health. 2013;52(5):539545.

17. Gadomski AM, Scribani MB, Krupa N, et al. Do the Guidelines for Adolescent Preventive Services (GAPS) Facilitate Mental Health Diagnosis? J Prim Care Community Health. 2014;5(2):85-89. 
medRxiv preprint doi: https://doi.org/10.1101/2021.04.29.21256334; this version posted May 1, 2021. The copyright holder for this preprint

(which was not certified by peer review) is the author/funder, who has granted medRxiv a license to display the preprint in perpetuity. It is made available under a CC-BY-NC-ND 4.0 International license .

18. Samples H, Stuart EA, Saloner B, et al. The Role of Screening in Depression Diagnosis and Treatment in a Representative Sample of US Primary Care Visits. J Gen Intern Med. 2019:1-9.

19. Brignone E, George DR, Sinoway L, et al. Trends in the diagnosis of diseases of despair in the United States, 2009-2018: a retrospective cohort study. BMJ Open. 2020;10(10):e037679.

20. Sekhar DL, Ba DM, Liu G, et al. Major Depressive Disorder Screening Remains Low Even Among Privately Insured Adolescents. Journal Pediatr. 2019;204:203-207.

21. Rushton JL, Felt BT, Roberts MW. Coding of pediatric behavioral and mental disorders. Pediatrics. 2002;110(1):e8-e8.

22. Fiest KM, Jette N, Quan H, et al. Systematic review and assessment of validated case definitions for depression in administrative data. BMC Psychiatry. 2014;14(1):289.

23. Imai K, Khanna K. Improving ecological inference by predicting individual ethnicity from voter registration records. Polit Anal. 2016:263-272.

24. Michigan Population Studies Cemter. Zip Code Characteristics: Mean and Median Household Income. Accessed January 21, 2021.

https://www.psc.isr.umich.edu/dis/census/Features/tract2zip/

25. Austin PC. An Introduction to Propensity Score Methods for Reducing the Effects of Confounding in Observational Studies. Multivariate Behav Res. 2011;46(3):399-424.

26. Green KM, Stuart EA. Examining moderation analyses in propensity score methods: application to depression and substance use. J Consult Clinical Psychol. 2014;82(5):773783.

27. VanderWeele TJ, Ding P. Sensitivity Analysis in Observational Research: Introducing the E-Value. Ann Intern Med. 2017;167(4):268-274.

28. Hacker K, Arsenault L, Franco I, et al. Referral and Follow-Up After Mental Health Screening in Commercially Insured Adolescents. J Adolesc Health. 2014;55(1):17-23.

29. Hacker KA, Penfold RB, Arsenault LN, et al. Behavioral Health Services Following Implementation of Screening in Massachusetts Medicaid Children. Pediatrics. 2014;134(4):737-746.

30. Sudhanthar S, Thakur K, Sigal Y, et al. Improving validated depression screen among adolescent population in primary care practice using electronic health records (EHR). BMJ Qual Improv Rep. 2015;4(1):u209517.w203913.

31. Chisolm DJ, Klima J, Gardner W, et al. Adolescent Behavioral Risk Screening and Use of Health Services. Adm Policy Ment Health. 2009;36(6):374.

32. Gardner W. Screening for Mental Health Problems: Does It Work? J Adolesc Health. 2014;55(1):1-2.

33. Clement S, Schauman O, Graham T, et al. What is the impact of mental health-related stigma on help-seeking? A systematic review of quantitative and qualitative studies. Psychol Med. 2015;45(1):11-27.

34. Oliffe JL, Phillips MJ. Men, depression and masculinities: A review and recommendations. J Mens Health. 2008;5(3):194-202.

35. Radovic A, Reynolds K, McCauley HL, et al. Parents' Role in Adolescent Depression Care: Primary Care Provider Perspectives. J Pediatr. 2015;167(4):911-918.

36. Kelleher KJ, Hoagwood K. Beyond Blame: Parents as Partners. J Pediatr. 2015;167(4):795-796. 
medRxiv preprint doi: https://doi.org/10.1101/2021.04.29.21256334; this version posted May 1, 2021. The copyright holder for this preprint

(which was not certified by peer review) is the author/funder, who has granted medRxiv a license to display the preprint in perpetuity.

It is made available under a CC-BY-NC-ND 4.0 International license .

37. Gurney BA, German M, Keller K, et al. Increasing behavioral health appointment attendance using warm handoffs in an integrated primary care setting. The Behavior Therapist. 2020;43(1):14-19.

38. Germán M, Hsu-Walklet T, Gurney BA, et al. "Nice to meet you": A quality improvement project to increase warm handoffs. Clin Pract Pediatr Psychol. 2020;8(3):247-256.

39. Murphy JM, Stepanian S, Riobueno-Naylor A, et al. Implementation of an Electronic Approach to Psychosocial Screening in a Network of Pediatric Practices. Acad Pediatr. In Press.

40. Honigfeld L, Macary SJ, Grasso DJ. A Clinical Care Algorithmic Toolkit for Promoting Screening and Next-Level Assessment of Pediatric Depression and Anxiety in Primary Care. J Pediatr Health Care. 2017;31(3):e15-e23.

41. Arauz-Boudreau A, Riobueno-Naylor A, Haile H, et al. How an Electronic Medical Record System Facilitates and Demonstrates Effective Psychosocial Screening in Pediatric Primary Care. Clin Pediatr. 2019;59(2):154-162.

42. Findling RL, Stepanova E. The Workforce Shortage of Child and Adolescent Psychiatrists: Is It Time for a Different Approach? J Am Acad Child Adolesc Psychiatry. 2018;57(5):300-301.

43. Walters AS. 10 months in: Telemental health for children and adolescents during the COVID-19 pandemic. Brown Univ Child Adolesc Behav Lett. 2021;37(2):8-8.

44. Townsend L, Walkup JT, Crystal S, et al. A systematic review of validated methods for identifying depression using administrative data. Pharmacoepidemiol Drug Saf. 2012;21:163-173. 
Table 1. Descriptive characteristics for complete and matched samples, N (\%).

\begin{tabular}{|c|c|c|c|}
\hline \multirow[b]{2}{*}{ Variable } & \multirow[b]{2}{*}{$\begin{array}{c}\text { Complete Sample } \\
(\mathrm{n}=\mathbf{2 4 8 , 3 5 4 )}\end{array}$} & \multicolumn{2}{|c|}{ Matched Sample $(\mathrm{n}=57,732)$} \\
\hline & & $\begin{array}{c}\text { Not Screened } \\
(n=43,299)\end{array}$ & $\begin{array}{l}\text { Screened } \\
(n=14,433)\end{array}$ \\
\hline \multicolumn{4}{|l|}{ Covariates } \\
\hline $\mathrm{Age}^{\mathrm{a}}$ & $14.26(2.06)$ & $13.68(1.98)$ & $13.69(1.96)$ \\
\hline \multicolumn{4}{|l|}{ Sex } \\
\hline Female & $121,432(48.9 \%)$ & $21,375(49.4 \%)$ & $7,125(49.4 \%)$ \\
\hline Male & $126,922(51.1 \%)$ & $21,924(50.6 \%)$ & $7,308(50.6 \%)$ \\
\hline \multicolumn{4}{|l|}{ Race/Ethnicity ${ }^{\mathrm{a}, \mathrm{b}}$} \\
\hline Asian & $0.02(0.11)$ & $0.03(0.12)$ & $0.03(0.12)$ \\
\hline Black & $0.07(0.17)$ & $0.07(0.18)$ & $0.08(0.18)$ \\
\hline Hispanic/Latino & $0.07(0.18)$ & $0.05(0.16)$ & $0.05(0.17)$ \\
\hline Other & $0.02(0.04)$ & $0.01(0.03)$ & $0.01(0.04)$ \\
\hline White & $0.82(0.28)$ & $0.83(0.26)$ & $0.83(0.27)$ \\
\hline \multicolumn{4}{|l|}{ Rurality } \\
\hline Urban & $199,569(80.4 \%)$ & $37,914(87.6 \%)$ & $12,670(87.8 \%)$ \\
\hline Large Rural City/Town & $30,039(12.1 \%)$ & $3,883(9.0 \%)$ & $1,237(8.6 \%)$ \\
\hline Small/Isolated Rural Town & $18,746(7.5 \%)$ & $1,502(3.5 \%)$ & $526(3.6 \%)$ \\
\hline \multicolumn{4}{|l|}{ Year of Index Well-Visit } \\
\hline 2014 & $117,743(47.4 \%)$ & $6,968(16.1 \%)$ & $2,314(16.0 \%)$ \\
\hline 2015 & $54,054(21.8 \%)$ & $10,362(23.9 \%)$ & $3,373(23.4 \%)$ \\
\hline 2016 & $40,024(16.1 \%)$ & $11,467(26.5 \%)$ & $3,775(26.2 \%)$ \\
\hline 2017 & $36,533(14.7 \%)$ & $14,502(33.5 \%)$ & $4,971(34.4 \%)$ \\
\hline Emergency Health Services Use ${ }^{a}$ & $0.18(0.52)$ & $0.21(0.58)$ & $0.21(0.54)$ \\
\hline Routine Health Services Use ${ }^{\mathrm{a}}$ & $0.85(1.84)$ & $0.72(1.50)$ & $0.73(1.61)$ \\
\hline Physical Health Comorbidities ${ }^{\mathrm{a}}$ & $0.12(1.50)$ & $0.09(0.65)$ & $0.10(0.84)$ \\
\hline ZIP-Level Median Income ${ }^{a}$ & $55,886.52(19,086.55)$ & $58,219.29(20,148.41)$ & $58,107.51(19,806.49)$ \\
\hline \multicolumn{4}{|l|}{ Provider Specialty } \\
\hline Child- or Adolescent-Specific & $159,647(64.3 \%)$ & $38,984(90.0 \%)$ & $12,935(89.6 \%)$ \\
\hline Family-Specific & $67,957(27.4 \%)$ & $2,640(6.1 \%)$ & $909(6.3 \%)$ \\
\hline Other Primary Care & $20,750(8.4 \%)$ & $1,675(3.9 \%)$ & $589(4.1 \%)$ \\
\hline \multicolumn{4}{|l|}{ Outcomes } \\
\hline Depression Diagnosis $^{\mathrm{c}}$ & $4,730(1.9 \%)$ & $761(1.8 \%)$ & $329(2.3 \%)$ \\
\hline Mood-Related Diagnosis ${ }^{c}$ & $13,591(5.5 \%)$ & $2,426(5.6 \%)$ & $948(6.6 \%)$ \\
\hline Antidepressant Prescription ${ }^{c}$ & $1,330(0.5 \%)$ & $224(0.5 \%)$ & $83(0.6 \%)$ \\
\hline Any Mental Health Prescription ${ }^{c}$ & $5,182(2.1 \%)$ & $972(2.2 \%)$ & $374(2.6 \%)$ \\
\hline Psychotherapy $^{\mathrm{c}}$ & $6,394(2.6 \%)$ & $1,295(3.0 \%)$ & $488(3.4 \%)$ \\
\hline
\end{tabular}

Notes: ${ }^{a}$ Reported as mean (standard deviation). ${ }^{b}$ Race/ethnicity is a predicted probability based on the $w r u$ package in R. ${ }^{\mathrm{c}}$ Cells report the count and proportion of adolescents with the outcome. Bold font indicates statistical significance. 
Table 2. Propensity-score adjusted association of depression screening with diagnostic and treatment-related outcomes, in the matched sample $(n=57,732)$ and stratified by sex.

\begin{tabular}{|c|c|c|c|c|c|c|c|}
\hline \multirow[b]{3}{*}{ Outcome } & \multirow{2}{*}{\multicolumn{2}{|c|}{$\begin{array}{c}\text { Main Association of } \\
\text { Depression Screening }\end{array}$}} & \multicolumn{5}{|c|}{ With Interaction Term Between Depression Screening and Sex } \\
\hline & & & \multicolumn{2}{|c|}{ Females } & \multicolumn{2}{|c|}{ Males } & \multirow{2}{*}{$\begin{array}{l}\text { p-value for } \\
\text { difference }\end{array}$} \\
\hline & $\mathbf{R R}$ & $95 \% \mathrm{CI}$ & $\mathbf{R R}$ & $95 \%$ CI & RR & $95 \%$ CI & \\
\hline Depression Diagnosis & 1.30 & 1.11, 1.52 & 1.42 & $1.17,1.71$ & 1.12 & $0.87,1.44$ & 0.172 \\
\hline $\begin{array}{l}\text { Mood-Related } \\
\text { Diagnosis }\end{array}$ & 1.17 & $1.08,1.27$ & 1.26 & $1.12,1.40$ & 1.06 & $0.93,1.22$ & 0.070 \\
\hline $\begin{array}{l}\text { Antidepressant } \\
\text { Prescription }\end{array}$ & 1.11 & $0.82,1.51$ & 1.28 & $0.89,1.84$ & 0.85 & $0.51,1.44$ & 0.286 \\
\hline $\begin{array}{l}\text { Any Mental Health } \\
\text { Prescription }\end{array}$ & 1.15 & $0.87,1.53$ & 1.23 & $0.99,1.53$ & 1.10 & $0.92,1.32$ & 0.633 \\
\hline Psychotherapy & 1.13 & $0.98,1.31$ & 1.22 & $1.05,1.43$ & 1.02 & $0.84,1.23$ & 0.175 \\
\hline
\end{tabular}

Notes: Bold font indicates statistical significance. 
medRxiv preprint doi: https://doi.org/10.1101/2021.04.29.21256334; this version posted May 1, 2021. The copyright holder for this preprint (which was not certified by peer review) is the author/funder, who has granted medRxiv a license to display the preprint in perpetuity.

It is made available under a CC-BY-NC-ND 4.0 International license .

Figure 1. Plot of absolute standardized mean differences for covariates, before (pink) and after (blue) propensity score matching.

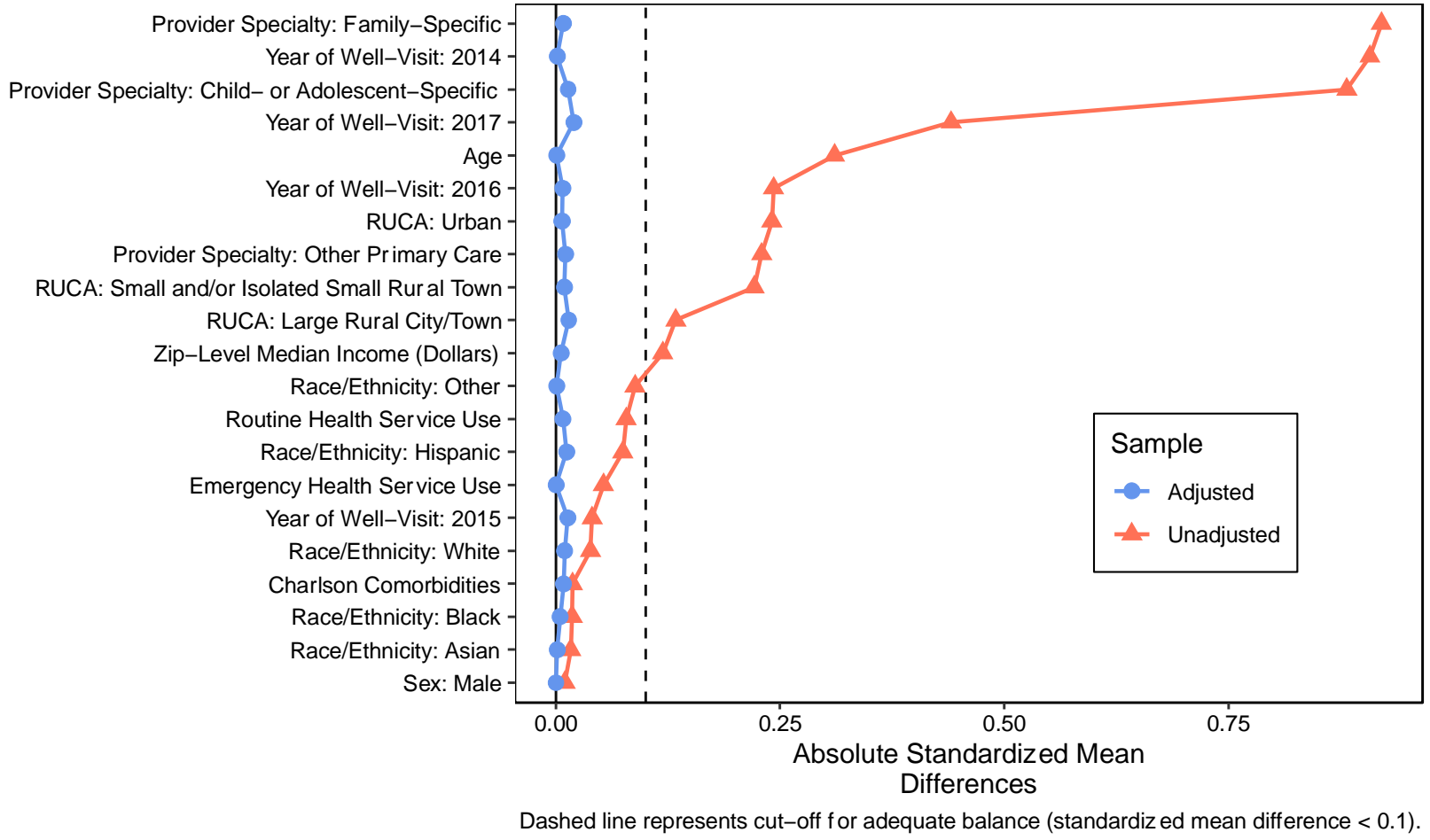


medRxiv preprint doi: https://doi.org/10.1101/2021.04.29.21256334; this version posted May 1, 2021. The copyright holder for this preprint (which was not certified by peer review) is the author/funder, who has granted medRxiv a license to display the preprint in perpetuity.

It is made available under a CC-BY-NC-ND 4.0 International license .

Figure 2. Percentage of adolescents screened for depression at the index well-visit from 20142017.

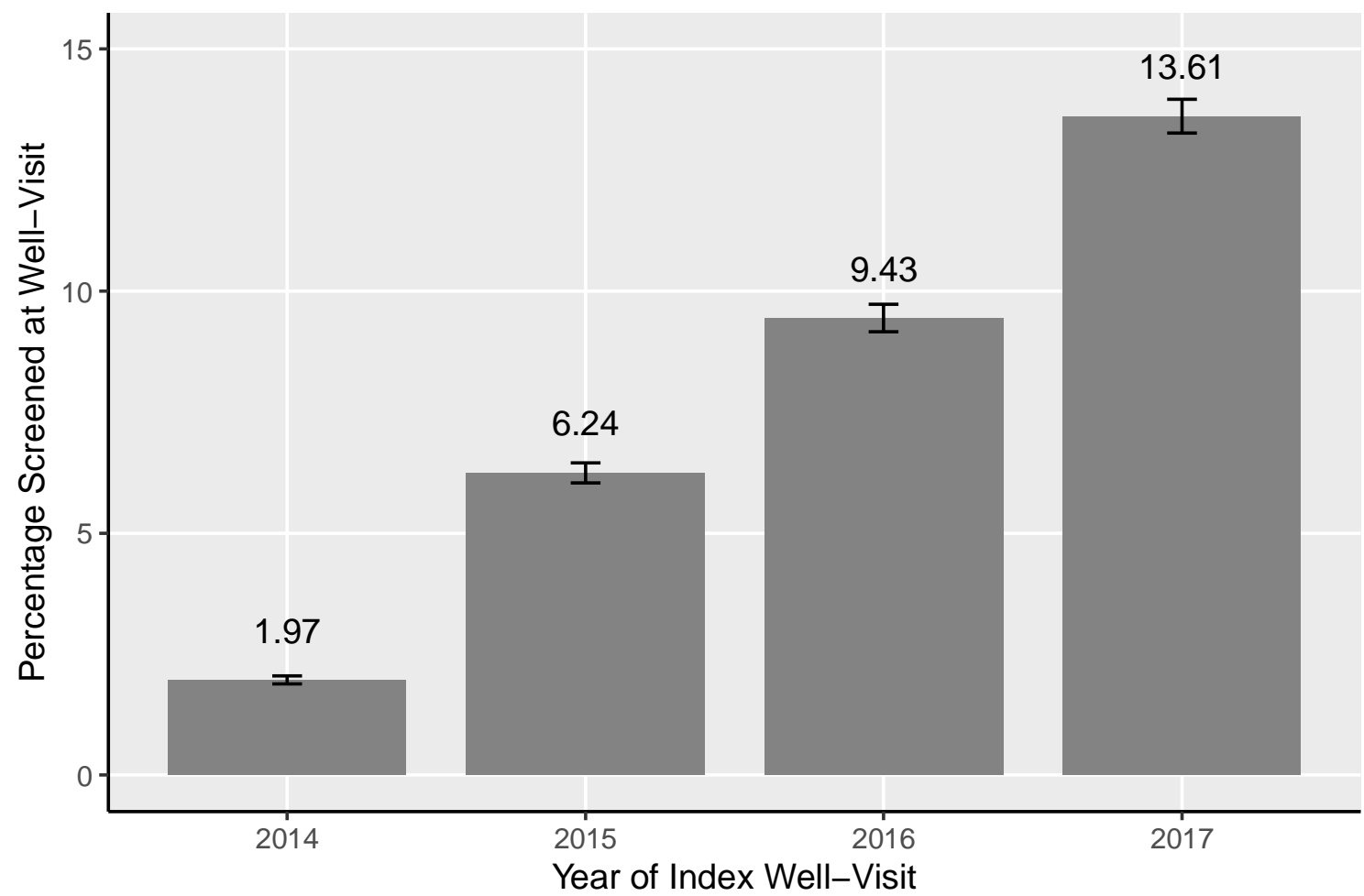

